\title{
S1. Supplementary information
}

Supplementary figures are included to further explain models, methodology, and processing of the datasets.

The supplementary material is conveyed under the same copyright terms and licence as the manuscript (CC BY 4.0 International). 


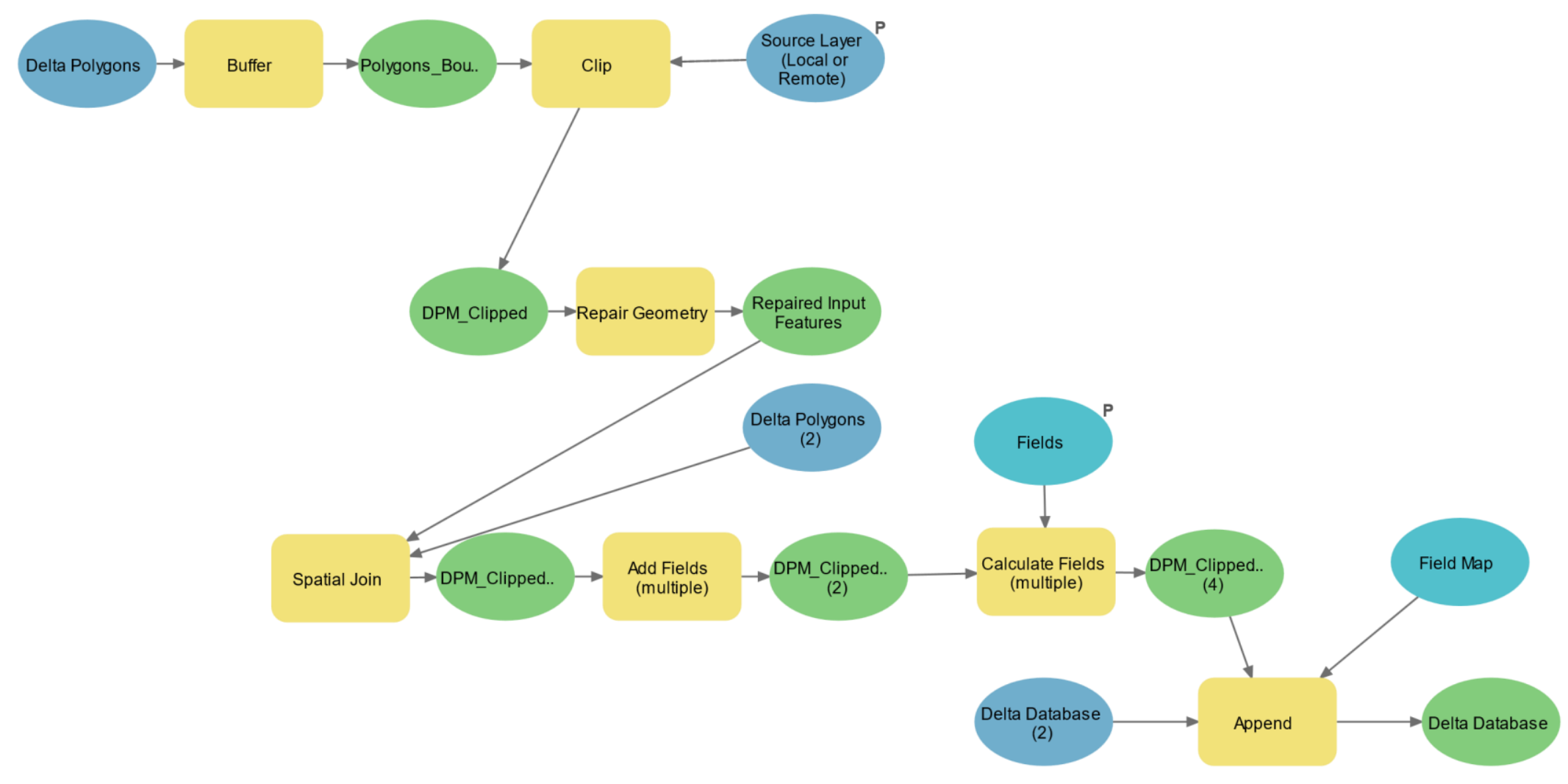

Supplementary Figure S1: ArcGIS Pro® Model Builder output for processing vector data for line and area data sources into the database. The first layer uses simple geometric processing to create a buffer zone around the existing delta polygons and clip the input layer to this area. The second layer repairs any geometrical errors. The third layer maps each of the input features to the parent delta polygon and writes element level attribute data. The fourth and final layer maps attributes and recalculates any units to the units used in the database. The model is accompanied by an interactive GUI with helptext which is stored in the metadata file. 


\begin{tabular}{|c|c|c|c|c|}
\hline $\begin{array}{l}\text { Source } \\
\text { Database }\end{array}$ & $\begin{array}{llll}\text { Source } & \text { Database } & \text { Field } & \text { Name } \\
\text { (Synonym) } & & & \end{array}$ & $\begin{array}{l}\text { Unit of } \\
\text { measure } \\
\text { (Source) }\end{array}$ & $\begin{array}{l}\text { Unit of } \\
\text { measure } \\
\text { (Layer) }^{1}\end{array}$ & $\begin{array}{l}\text { Master database field } \\
(\text { Term })^{3}\end{array}$ \\
\hline \multirow{9}{*}{$\begin{array}{l}\text { US Army Corps } \\
\text { of Engineers } \\
\text { National Levee } \\
\text { Database }\end{array}$} & FLOOD_SOURCE & - & - & NAME \\
\hline & FLOODWAAL_ID OR LEVEE_ID & - & - & REFERENCE \\
\hline & LENGTH_METERS & Metres & Metres & DefenceLength \\
\hline & WALL_HEIGHT & Metres & Metres & DefenceHeight \\
\hline & WALL_WIDTH OR CREST_WIDTH & US Feet & Metres & DefenceWidth \\
\hline & FOUNDATION_WIDTH & US Feet & Metres & FoundationWidth \\
\hline & PRIMARY_MATERIAL & - & - & Construction \\
\hline & WALLTYPE, LEVEE_TYPE & - & - & ClassType \\
\hline & CUTOFF_TYPE & - & - & CutoffMaterial \\
\hline \multirow{5}{*}{$\begin{array}{c}\text { GB } \\
\text { Environment } \\
\text { Agency Asset } \\
\text { Information } \\
\text { Management } \\
\text { System }\end{array}$} & asset_name & - & - & NAME \\
\hline & asset_ref & - & - & REFERENCE \\
\hline & eff_crest & $\mathrm{mAOD}^{2}$ & Metres & DefenceHeight \\
\hline & sub_type & - & - & ClassType \\
\hline & dessop & $\mathrm{n} / 1$ & $1 / \mathrm{n}$ (decimal) & DesignStandard \\
\hline \multirow{2}{*}{$\begin{array}{c}\text { AU Western } \\
\text { Australia FPM } \\
\text { Levee Banks } \\
\text { (DWER-021) }\end{array}$} & location & - & - & NAME \\
\hline & ufi & - & - & REFERENCE \\
\hline \multirow{4}{*}{$\begin{array}{c}\text { NL } \\
\text { Rijkswaterstaat } \\
\text { Dijkring }\end{array}$} & DIJKR1 AND NM_WATER1 & - & - & NAME \\
\hline & DIJKNR1 & - & - & REFERENCE \\
\hline & WK_TYPE [Dutch] & - & - & ClassType \\
\hline & NORM & $\mathrm{n} / 1$ & 1/n (decimal) & DesignStandard \\
\hline
\end{tabular}

Supplementary Table S2: Synonyms and units of measure in source vector datasets. ${ }^{1}$ Conversions from customary units were made according to NIST Guide to the SI conversation factors 15 (NIST Special Publication 811, Appendix B.8, https://www.nist.gov/pml/special-publication-811). ${ }^{2}$ No adjustment was made for values recorded mAOD (OSGB Newlyn) on account of the fact the delta areas contained in this dataset were at coastal interfaces and thus assumed to be within reasonable range of the datum. ${ }^{3}$ Fields are only from vector national databases and only where they match the core fields. This tables does not represent all fields in the database. 


\section{Raster data interpretation process}

Where we could find levee data, but no information on leveed area was found (such as the Australian levee datasets, but also some raster sources where only levee area was detailed) then we developed a manual analysis to decide the area protected by a levee.

Our interpretation made use of the following factors:

- Location of levees relative to rivers

- Topographical changes in the proximal area (verified using satellite imagery)

- Presence of other hydrological features that inhibit levee function

- Best-effort estimation of levee protection

Where necessary, we decided the following constraints were to be applied:

- Where the levee forms an enclosed shape, no vertices were to be added

- Where this was not possible, a minimal number of additional vertices were added, so that the leveed area remained realistic, but the outline of the levee features remained true to the source data

- Where the levee followed a coastline or other clearly defined feature (e.g. road, railway, sea wall), and this was confirmed in satellite imagery to have an elevation difference, this was sparingly used to ensure that the leveed area remained a complete shape

- Where a levee feature crossed a water body, two separate shapes were drawn but with reference to the same source dataset

- With respect to the age and purpose of the data, where contradictory data was received, it was reviewed together with the satellite imagery and the decision made was entered into the delta index.

20

Supplementary Figure S3: Manual interpretative process for creation of levee areas where only linear data were available 